\title{
Study of sorption and desorption of Cd (II) from aqueous solution using isolated green algae Chlorella vulgaris
}

\author{
Mahendra Kumar $^{1}$ (D) Alak Kumar Singh ${ }^{2} \cdot$ Mohd. Sikandar $^{1}$
}

Received: 10 July 2018 / Accepted: 7 November 2018 / Published online: 16 November 2018

(c) The Author(s) 2018

\begin{abstract}
In the present investigation, isolated green algae Chlorella vulgaris has been proven to be a very effective and promising adsorbing biomaterial for $\mathrm{Cd}$ (II) removal from aqueous solution in batch experiments. Adsorption features of algae were studied as function of time, $\mathrm{pH}$, initial $\mathrm{Cd}$ (II) concentration and algal biomass dosages. Kinetics and adsorption equilibrium isotherms of algal biomass were obtained for batch experiments. Kinetic data were best fitted to the pseudo-second-order where adsorption capacity $\left(q_{\mathrm{e}}\right)$ values agree to experimental values. Langmuir isotherm model which shows the existence of monolayer adsorption under the experimental conditions best fitted to the obtained equilibrium data. The maximum adsorption capacity calculated by Langmuir model was $97.43 \mathrm{mg} / \mathrm{g}$. FTIR, SEM, metal mapping were performed for virgin algal biomass and biomass loaded with $\mathrm{Cd}$ (II) to analyze the mechanism of adsorption. The various parameters of thermodynamics viz, $\Delta H, \Delta G$ and $\Delta S$, show endothermic, feasible and spontaneous behaviour, respectively, in sorption process. Desorption experiments were carried out insight of various parameters which resulted 0.1 M EDTA had commanding recovery of Cadmium metal ions. Recyclability study of algal biomass indicates promising future as it remains unaffected after five cycles with very less adsorption capacity loss $(5.8 \%)$.
\end{abstract}

Keywords Biosorption $\cdot$ Cd (II) $\cdot$ Chlorella vulgaris $\cdot$ Thermodynamics

\section{Introduction}

The presence of toxic heavy metals in the industrial effluents raises concern over their acute toxicity to human health (Mohapatra and Anand 2007; Leyva-Ramos et al. 1997). Among the hazardous toxic metals, cadmium $\left(\mathrm{Cd}^{2+}\right)$ is one of the most toxic heavy elements to which man can be exposed. Accumulating in human kidney cortex causes malfunction of kidney (Sethi et al. 2006; Nordberg 2009; Järup et al. 1998). The maximum limit suggested by the WHO is summarized in Table 1.

Cadmium is mainly used in the rechargeable batteries, production of special alloys, solar cells and coating (electroplating) (Katırcıoğlu et al. 2008).New revealing approaches

Mahendra Kumar

mahendra.bbt@gmail.com

1 Uttar Pradesh Pollution Control Board, Kanpur Fase-3, Sadbhawna Nagar, Kalyanpur, Kanpur, Uttar Pradesh 208001, India

2 Department of Food Technology, Harcourt Butler Technical University, Kanpur, Uttar Pradesh 208002, India such as membrane filtration, hybrid methods (floatation-filtration) are very costly and not feasible when metals are in huge volumes at relatively low concentrations, i.e. less than 100 ppm (Patterson 1985; Rao and Gupta 1982; Blöcher et al. 2003). In recent times, while important advances in knowledge have come out, biosorption proved to be an effective technology in industrial and environmental remediation of toxic heavy metals (Eccles 1999). Among the diverse types of biosorbents (i.e. fungi, bacteria, algae, lignocellulosic materials, industrial waste), algal biomass has proven to be a highly effective and economical technology for its ability to remediate/adsorb toxic metals (Ramelow et al. 1992; Holan and Volesky 1994).

In the present study, isolated green algae Chlorella vulgaris was used as biosorbents with an objective of removing $\mathrm{Cd}$ (II) from industrial effluents. It examines the importance of green algae Chlorella vulgaris as a potential biosorbent which was characterized by morphological parameters by employing scanning electron microscope (SEM) equipped with energy-dispersive spectroscopy (EDX) and various functional groups involved in adsorption by FTIR analysis. It also includes isolation of green algae Chlorella vulgaris, 
Table 1 Maximum limits of heavy metals suggested by the World health organization (WHO)

\begin{tabular}{lll}
\hline S1. no. & Metal & $\begin{array}{l}\text { Upper limit of } \\
\text { concentration } \\
\text { (ppm) }\end{array}$ \\
\hline 1 & $\mathrm{~Pb}(\mathrm{II})$ & 0.05 \\
2 & $\mathrm{Cd}(\mathrm{II})$ & 0.01 \\
3 & $\mathrm{Cr}(\mathrm{VI})$ & 0.05 \\
4 & $\mathrm{Ni}(\mathrm{II})$ & 0.05 \\
\hline
\end{tabular}

the effect of various fundamental parameters over sorption process, adsorption isotherms and kinetics that are at play in the biosorption of $\mathrm{Cd}$ (II) by green algae Chlorella vulgaris. This study is also devoted to outlining the importance of desorption of $\mathrm{Cd}$ (II) with many affecting parameters and recovery of metal ions.

\section{Materials and methods}

\section{Microalgae strain and mass culture}

The algal samples were collected from the water pond in Harcourt Butler Technological university campus, Kanpur. The samples were inoculated in the autoclaved Fog's medium in 100-mL test tubes at room temperature in open laboratory in natural sunshine (17:7 h photoperiod) for forty days (Becker 1994). Culture was streaked in agar plates of same medium and by using standard manual for algae, and Chlorella vulgaris was confirmed. The isolated algae Chlorella vulgaris were inoculated in $200 \mathrm{~mL}$ fog's medium in a 250-ml flask, were put in a shaker for one week in room temperature $\left(35 \pm 2{ }^{\circ} \mathrm{c}\right)$ in white florescent light of moderate intensity and stepwise transferred to $500 \mathrm{~mL}$ and then to one litre flasks up to $90 \%$ of its capacity. Growth was monitored by measuring OD at a wavelength of $686 \mathrm{~nm}$ (PiotrowskaNiczyporuk et al. 2012).

Dry weight of algae was calculated by using the relation:

Biomass (dry weight) $(x)=0.2936 *$ O.D. $686 \mathrm{~nm}+0.0007$

\section{Preparation of metal ion solution}

A stock solution of Cd (II) was prepared by dissolving 2.744 gm of cadmium nitrate $\mathrm{Cd}\left(\mathrm{NO}_{3}\right) \cdot 4 \mathrm{H}_{2} \mathrm{O}$ in $1000 \mathrm{ml}$ of deionized water. All the chemicals used in the experiment were procured from Merck and of analytical grade. Prepared working solutions of different concentrations from stock solution with adequate dilution Standard solutions of $\mathrm{Cd}$ (II) were obtained from BIS (Bureau of Indian Standards), Delhi, India.

\section{Preparation of adsorbent}

The biosorbent used in this work was harvested by filtering the culture medium through cellulose nitrate membrane filter of pore size $45 \hat{A} \mu \mathrm{m}$. The filtered biomass was washed several times with distilled water and dried in an oven at $60{ }^{\circ} \mathrm{C}$ for 1 day (Yadav et al. 2014). They were made of size $250-300 \mu \mathrm{m}$ by sieving and stored in a desiccator.

\section{Characterization of the adsorbent}

The elemental composition of biosorbents was analyzed by using elemental analyzer (Eurovector EA 3000, Germany), and functional groups present on the surface of algal biosorbents were analyzed by Fourier transform infrared (FTIR) spectroscopy (Bruker FTIR Vertex 70, Germany) in the specified range. Scanning electron microscope (SEM, Zeiss, Sigma VP, with EDAX) was used to see the surface morphology of biosorbent. Double-beam UV-VIS spectrophotometer (UV Pharmspec 1700, Shimadzu) was used for algal growth estimation, and Atomic absorption spectrophotometer (AA240, Agilent) was used for estimation of adsorbed heavy metal.

\section{Adsorption experiment}

Kinetic experiment was performed in continuously stirred flasks $(250 \mathrm{~mL})$ containing $100 \mathrm{ml}$ of stock solutions of different concentrations and $1 \mathrm{~g}$ of biosorbent. Sample of $2 \mathrm{ml}$ solution was withdrawn in specific regular intervals and analyzed by AAS at $480 \mathrm{~nm}$ for residual Cd solution (Yadav et al. 2013). Initial batch sorption experiments were carried out for optimization of $\mathrm{pH}(1-6)$,

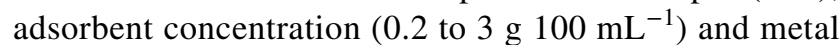
concentration (10-120 $\left.\mathrm{mg} \mathrm{L}^{-1}\right)$. Experiments were carried out at room temperature $35^{\circ} \mathrm{C}$, and $\mathrm{pH}$ of solution was adjusted by $0.1 \mathrm{~N} \mathrm{HCl}$ or $0.1 \mathrm{~N} \mathrm{NaOH}$. The percentages of Cd removal ' $\mathrm{R}$ ' and $\mathrm{q}_{\mathrm{e}}(\mathrm{mg} / \mathrm{g})$, that is amount of metals adsorbed per unit of the mass of the adsorbent, were determined using formulas (2) and (3) (Chen et al. 2005).

Removal of Cd (II) (\%) $R=\left(C_{\mathrm{i}}-C_{\mathrm{e}} / C_{\mathrm{i}}\right) 100$

Cd (II) uptake $\left(q_{\mathrm{e}}\right)=\left(C_{\mathrm{i}}-C_{\mathrm{e}} / M\right) V$

where $C_{\mathrm{i}}$ and $C_{\mathrm{e}}(\mathrm{mg} / \mathrm{L})$ are initial and equilibrium concentrations, $V$ is volume of solution (L) and $M$ is the weight of adsorbents (g).

\section{Desorption experiments}

For the desorption study, algal biomass (0.1 g) was incorporated with $50 \mathrm{ml} \mathrm{Cd}$ (II) solution (100 ppm). 
The loaded algal biomass was filtered and washed 2 to 3 times from distilled water. Further, it was treated with $50 \mathrm{ml}$ desorbent solutions $(0.1 \mathrm{~N})$ of each $\mathrm{HNO}_{3}$, EDTA, $\mathrm{HCl}, \mathrm{H}_{2} \mathrm{SO}_{4}$ separately. This mixture was kept for $2-3 \mathrm{~h}$ in shaker, and further collected supernatant was analyzed for Cd (II)(Hashim and Chu 2004). Desorption ratio was calculated from the amount of metal ions adsorbed on the biomass and the final metal ion concentration in desorption medium, as the following equation:

Desorption ratio $=($ Amount of metal ions desorbed /Amount of metal ions adsorbed) $\times 100$

Effect of time, temperature on desorption capacity, concentration vs desorption capacity on algal biomass were also evaluated.

\section{Kinetic study}

The most important factor in adsorption is predicting at what rate adsorption takes place in adsorption system design. Mechanism of biosorption and rate-controlling step are also essential outcomes in the kinetic study. When the initial concentration of solute is low, the adsorption process obeys the pseudo-second-order model. Conversely, pseudo-first-order models can be applied to higher initial concentrations (Azizian 2004).

Pseudo-first-order model

$\log \left(q_{\mathrm{e}}-q_{\mathrm{t}}\right)=\log q_{\mathrm{e}}-\left(k_{1} / 2.303\right) t$

where $\mathrm{q}_{\mathrm{t}}$ and $\mathrm{q}_{\mathrm{e}}$ are the amounts of metal ions adsorbed $(\mathrm{mg} / \mathrm{g})$ at time $\mathrm{t}$ and at equilibrium, respectively, and $\mathrm{k}_{1}$ is the rate constant of pseudo-first-order adsorption $\left(\mathrm{min}^{-1}\right)$ (Lagergren 1898).

\section{Pseudo-second-order model}

It is represented by the equation:

$t / q_{t}=1 /\left(k_{2} q_{\mathrm{e}}^{2}+\left(1 / q_{\mathrm{e}}\right) t\right.$

here $q_{\mathrm{e}}$ and $q_{t}$ are the adsorption capacities at equilibrium and time $\mathrm{t}(\mathrm{mg} / \mathrm{g})$, respectively, $k_{2}$ is the rate constant of the pseudo-second-order sorption (g/mg min). The plots of $t / q_{t}$ versus $t$ gave linear plot (Ho and McKay 1999). The values of the adsorption parameters $q_{\mathrm{e}}$ and $k_{2}$ were determined from the slope and intercept of the plot, respectively.

Intraparticle diffusion model

To know the mechanism and rate-controlling steps in the kinetic of biosorption, intraparticle diffusion model provides adequate information. The intraparticle diffusion model is (Weber and Carrell Morris 1963) given by Eq. (6):

$q_{t}=k_{\mathrm{i}} t^{0.5}+I$ where $\mathrm{k}_{\mathrm{i}}$ is the intraparticle diffusion rate constant and $\mathrm{I}$ is the intercept of the intraparticle diffusion plot. The value of $k_{\mathrm{i}}$ was calculated from the slope of plot $q_{\mathrm{t}} \mathrm{vs}^{0.5}$.

\section{Thermodynamic studies}

The thermodynamic parameters such as $\Delta H^{0}, \Delta S^{0}$ and $\Delta G^{0}$ were calculated from the adsorption data. Kc, the equilibrium constant was determined by Eq. (7) (Aksu 2002).

$\mathrm{Kc}=C_{\mathrm{A}} / C_{\mathrm{e}}$

where $C_{\mathrm{A}}(\mathrm{mg} / \mathrm{L})$ is the concentration of solute in the aqueous phase and $C_{\mathrm{e}}$ is the equilibrium concentration $(\mathrm{g} / \mathrm{L})$. Then, $\Delta G^{0}$ by expression:

$\Delta G^{0}=-R T \ln \mathrm{Kc}$

The value of $\Delta S$ and $\Delta H$ was determined by

$\log \mathrm{Kc}=\Delta S / 2.303-\Delta H / 2.303 \mathrm{RT}$

\section{Adsorption isotherms}

Various adsorption isotherm models have been investigated to find adsorption efficiency for metal ions from the solution. The maximum uptake of Cd (II) by algal adsorbent was determined by fitting the adsorption data to Langmuir and Freundlich. To investigate the prevalence of physical or chemical process in adsorbing heavy metal ions from aqueous solution, Dubinin-Radushkevich isotherm model was also studied.

\section{Langmuir isotherm model}

The Langmuir isotherm describes uniform adsorption with no cross-migration of adsorbate on a surface having finite number of adsorption sites that are monolayer adsorption (Langmuir 1916). To ensure equilibrium conditions, the linear form of the Langmuir isotherm model (Eq. 10) was applied to the experimental data as

$C_{\mathrm{e}} / q_{\mathrm{e}}=\left(1 / b q_{\mathrm{m}}\right)+\left(C_{\mathrm{e}} / q_{\mathrm{m}}\right)$

where $C_{\mathrm{e}}, q_{\mathrm{m}}$, and $b$ are the concentration of adsorbate at equilibrium $(\mathrm{mg} / \mathrm{L})$, maximum adsorption capacity $(\mathrm{mg} / \mathrm{g})$, and Langmuir constant (L/mg), respectively. Equation (10) expresses a dimensionless constant separation factor or equilibrium parameter $\left(R_{\mathrm{L}}\right)$ in Langmuir isotherm

$R_{\mathrm{L}}=\left(1 / 1+b C_{\mathrm{i}}\right)$

where the initial solute concentration is donated by $C_{\mathrm{i}}$ and b is the Langmuir's adsorption constant $(\mathrm{L} / \mathrm{mg})$. The $R_{\mathrm{L}}$ value confirms the adsorption to be unfavourable $\left(R_{\mathrm{L}}>1\right)$, linear $\left(R_{\mathrm{L}}=1\right)$, favourable $\left(0<R_{\mathrm{L}}<1\right)$, or irreversible $\left(R_{\mathrm{L}}=0\right)$. 


\section{Freundlich isotherm model}

The Freundlich isotherm is used as an empirical model for the adsorption process of heavy metal ions (Ho et al. 2005). Equation (12) describes the empirical Freundlich isotherm as:

$\ln q_{\mathrm{e}}=\ln K_{\mathrm{F}}+1 / n \ln C_{\mathrm{e}}$

where $q_{\mathrm{e}}$ is amount of metal ion adsorbed on to surface of algal biomass at equilibrium $(\mathrm{mg} / \mathrm{g})$ and $C_{\mathrm{e}}$ is the equilibrium concentration of the adsorbate $(\mathrm{mg} / \mathrm{L}) . \mathrm{K}_{\mathrm{F}}$ is the adsorption constant that corresponds to adsorption capacity whereas $1 / n$ to the adsorption intensity. $n$ depends on the adsorbate and adsorbent. Any value of $n$, higher than unity, favours the adsorption process.

\section{Results and discussion}

\section{Characterization of algal bioadsorbent}

\section{Algal growth}

The algal growth and increase in biomass were calculated by spectrophotometric method (McGinn et al. 2012). The biomass content obtained after 30 days $(0.332 \mathrm{~g} / \mathrm{L})$ was the greatest. The algal strain continued to show an increase in growth for 30 days after which the growth attained saturation as the cells entered in saturation phase. After 40 days, the cells started entering the decline phase showing a decrease in the biomass. Figure 1 shows growth curve of $C$. vulgaris.

\section{Elemental analysis}

To explain the mechanism and behaviour of sorption process, physiochemical parameters provide essential insights into the biosorption of metallic ions. The percentage of major elements $\mathrm{C}, \mathrm{H}, \mathrm{O}, \mathrm{N}, \mathrm{S}$ in powdered form of algae Chlorella vulgaris were presented in Table 2.
Table 2 Characteristics of parameters of algal biomass

\begin{tabular}{ll}
\hline Parameters & Value \\
\hline Moisture content & 76.1 \\
Carbon & $47.54 \%$, \\
Hydrogen & $7.1 \%$ \\
Oxygen & $38.63 \%$ \\
Nitrogen & $6.73 \%$ \\
Sulphur & $0.8 \%$ \\
Ash content & $11.93 \%$ \\
Surface area $\left(\mathrm{m}^{2} / \mathrm{g}\right)$ & 11.98 \\
Pore size (micrometer) & $3-9$ \\
\hline
\end{tabular}

The pore size of algal biosorbents was 3-9 micrometre, and the radii of cadmium ion was 95 pm (Pauling 1960). The smaller ionic radii of cadmium ion and larger pore size of algal biosorbent facilitate higher adsorption. Surface area of biosorbent plays an important role in the adsorption process. The average surface area of biosorbent was estimated about $12 \mathrm{~m}^{2} / \mathrm{g}$ which is very much favourable for the sorption of heavy metals.

\section{FTIR analysis}

FTIR analysis (Fig. 2) depicts the various peaks arisen due to various functional groups present on the surface of biosorbent. The broad peak around $3485 \mathrm{~cm}^{-1}$ belongs to $-\mathrm{NH}$ and $-\mathrm{OH}$ groups, stretching frequency around $2945 \mathrm{~cm}$ ${ }^{-1}$ attributed to $-\mathrm{CH}$, peak at 1674 shows the vibrational frequency of carbonyl $(\mathrm{C}=\mathrm{O})$ group, $1267 \mathrm{~cm}^{-1}$ assigned to $-\mathrm{CH}_{3}$ group(Sharma and Bhattacharyya 2005). The other lower peaks ascribed to $\mathrm{C}-\mathrm{N}$ and $-\mathrm{C}=\mathrm{S}$ groups (Tunali et al. 2006). After absorbing the $\mathrm{Cd}$ (II) ions, the various vibrational frequencies reduced which confirms the bonds formation by Cd (II) to carboxyl, carbonyl, hydroxy, amine and amido groups.
Fig. 1 Growth curve of $C$. vulgaris: temperature $\left(35 \pm 2{ }^{\circ} \mathrm{c}\right)$, OD at $686 \mathrm{~nm}$, time (till 40 days)

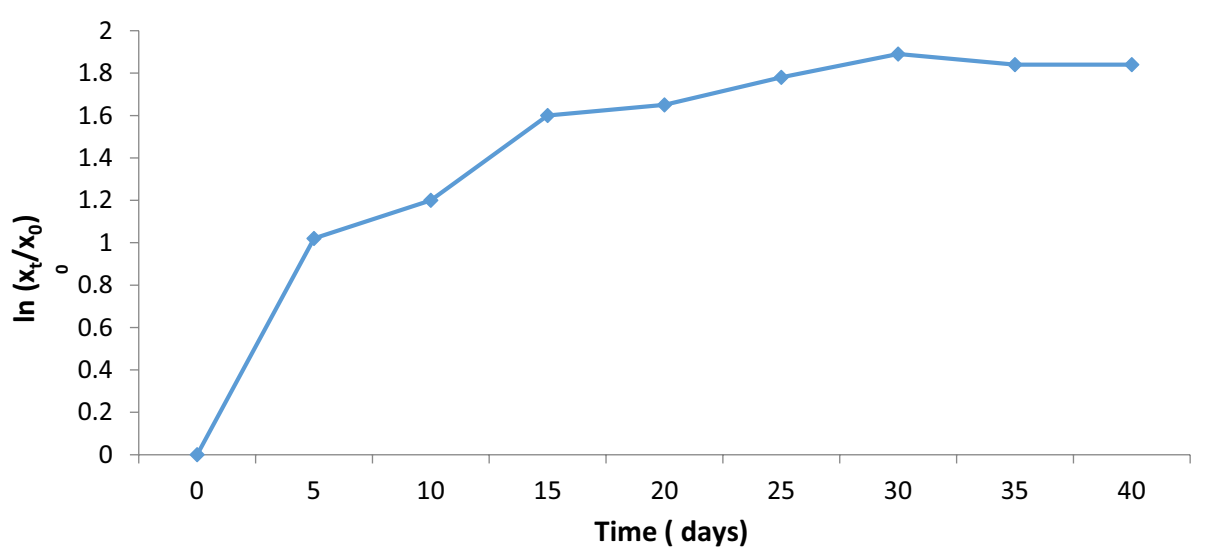


Fig. 2 FTIR spectra of virgin chlorella and loaded with $\mathrm{Cd}$ (II) metal ions

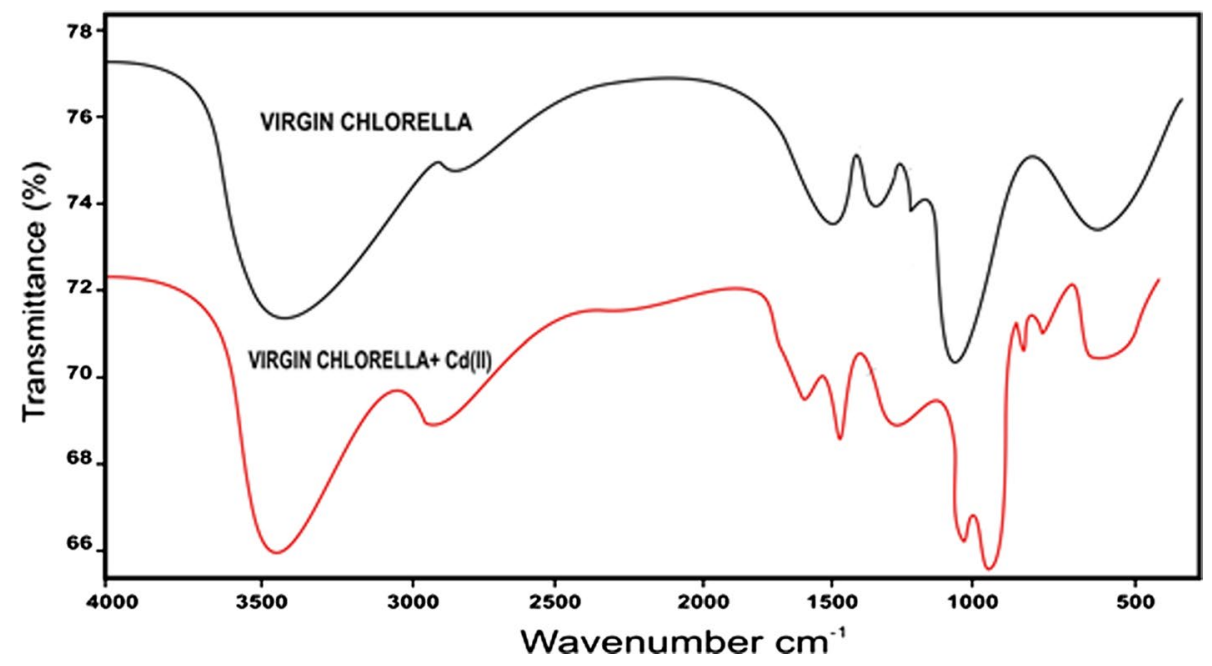

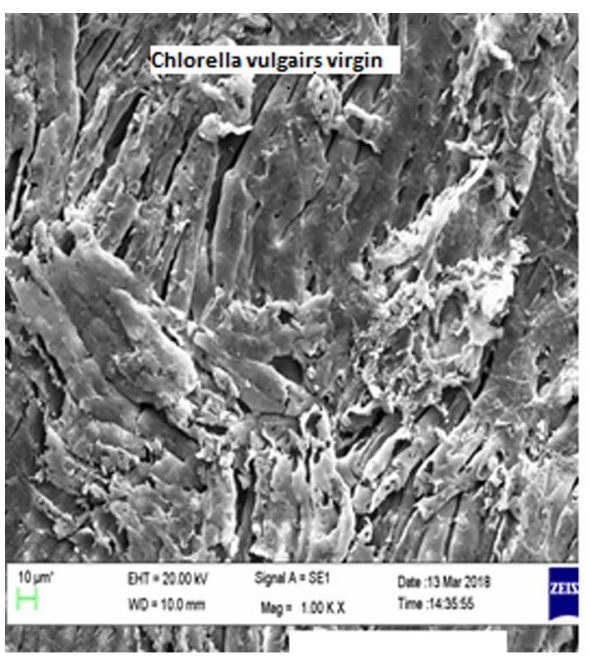

(a)

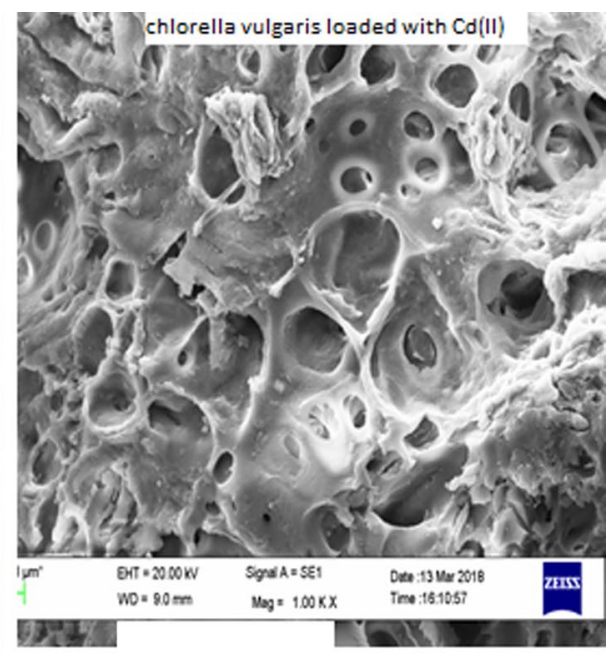

(b)

\section{SEM analysis}

The SEM-analyzed image of virgin algal biomass revealed the asymmetric porous, heterogeneous surface having cavities which facilitate the biosorption of the cadmium (II) ions on the surface of algal biomass Fig. 3a. After getting the metal adsorbed, the surface of algal biomass became smoother and compact Fig. 3b.

\section{Effect of solution $\mathrm{pH}$}

The hydrogen ion concentration is an important parameter affecting the adsorption. The degree of ionization of adsorbate and surface charge of adsorbent are very much influenced by the $\mathrm{pH}$. The batch sorption studies have been carried out within the $\mathrm{pH}$ range of $1-6$. The obtained results are shown in Fig. 4. Percentage removal of metal ions is comparatively very less at lower $\mathrm{pH}$ which revealed that higher hydrogen

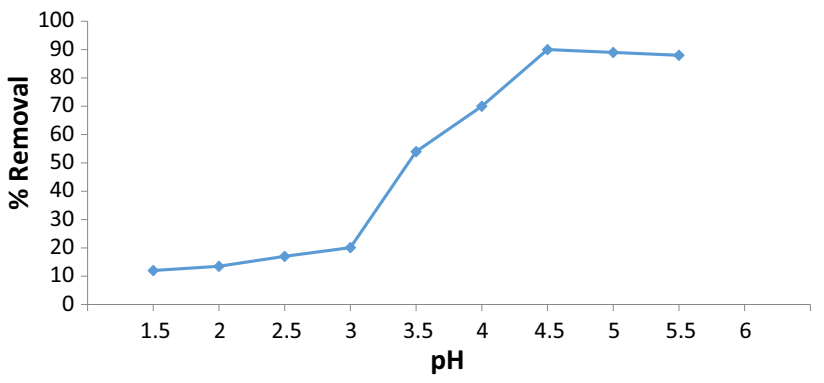

Fig. 4 Effect of $\mathrm{pH}$ on adsorption of Cd (II) on to Chlorella vulgaris biomass: $C_{\mathrm{i}}=100 \mathrm{mg} / \mathrm{L}$, dose $=1 \mathrm{~g} / \mathrm{L}$, contact time $=2 \mathrm{~h}$ and room temperature

ion concentrations compete to metal ions for site on adsorbent and it gets protonated which left very less site for the adsorption of metal ions(Lalhruaitluanga et al. 2010; Ibrahim and Sani 2014). About $90 \%$ of the removal takes place 
at $\mathrm{pH} 4.5$ which is the maximum in the present study. As $\mathrm{pH}$ increases deprotonation takes place and sites get available to the metal ions and that is the reason the percentage of removal increases (Ibrahim et al. 2006).

\section{Effect of initial metal concentration, contact time and biomass dosages}

The effect of initial metal concentrations was studied under batch conditions: $\mathrm{pH}=4.5$, dose $=1 \mathrm{~g} / \mathrm{L}$, contact time $2 \mathrm{~h}$ at room temperature of concentration range 10-100 ppm. As we increase the metal ion concentrations of cadmium (20 to $100 \mathrm{ppm}$ ), the biosorption capacity increases (16-62.3 mg/g), respectively. Figure 5a shows the fact that the increase in metal ion concentration decreases the mass transfer resistance between metal ions and biosorbents and that facilitated to reach the sites that's why adsorption capacity increases and after further increase in concentration have no effect on adsorption capacity due to the saturation of binding sites. At the same time, percentage removal decreases from 97.2 to 40.9 because at the lower initial concentration, a higher number of sites are available per mole of metal ions but as number of moles of metal ion increases(Nasir et al. 2007), sites were occupied by ions that lead to a decrease in the removal percentage shown in Fig. $5 b$.

In the case of contact time, adsorption rate increases with time and after getting maximum (saturation) it tends to adsorb metal with a constant rate as we can depict in Fig. 5c. It has been observed that initially till $50 \mathrm{~min}$, adsorption capacity increases significantly, and thereafter it proceeds at a slower rate comparatively and finally beyond $55 \mathrm{~min}$, no significant metal uptake rate observed.

To examine the effect of biosorbent dose $(0.5-2 \mathrm{~g} / \mathrm{L})$, batch sorption studies at fixed initial concentration of $100 \mathrm{mg} / \mathrm{L}$, contact time of $2 \mathrm{~h}$ and at room temperature was done. Here we observed increased metal biosorption by increasing biomass dosages because of increased active sites and available surface area (Shen et al. 2008). Here, we can see in Fig. 5d, after reaching the saturation or equilibrium (adsorbent dose approximately $2 \mathrm{~g} / \mathrm{L}$ ), metal uptake had become unchanged afterwards due to concentration gradient between the sorbent and sorbate.

\section{Adsorption kinetics}

Mechanism involved in biosorption was analyzed by three kinetic models: the pseudo-first-order kinetics, pseudosecond-order kinetics and intraparticle diffusion models by fitting experimental values. The kinetic parameters obtained at initial concentration $100 \mathrm{ppm}$ are summarized in Table 3.
Pseudo-first-order, pseudo-second-order kinetic model and intraparticle diffusion model

The calculated $\mathrm{q}_{\mathrm{e}}(24.9 \mathrm{mg} / \mathrm{g})$ value obtained from pseudofirst-order model did not fit properly with the experimental value $(62.3 \mathrm{mg} / \mathrm{g})$, and at same time the correlation coefficient value is not up to mark as shown in Fig. 6a which made it clear that this model does not describe the adsorption process (Oliveira et al. 2008).

It could be seen that the calculated $(65.9 \mathrm{mg} / \mathrm{g})$ and experimental values $(62.3 \mathrm{mg} / \mathrm{g})$ showed nice agreement in pseudo-second-order kinetic model. Figure $6 \mathrm{~b}$ shows the correlation coefficient is very much close to unity. These results concluded that the pseudo-second order kinetic model best describes the adsorption kinetics of the present study.

The linear plot of $q_{t}$ versus $t^{0.5}$ showed (Fig. 6c) that biosorption process has intraparticle diffusion which helps in defining the mechanism of adsorption, but intraparticle diffusion is not rate limiting because the line does not pass through the origin (Freundlich 1907; Mane et al. 2007) which revealed there might be some other kinetic models also which help in controlling the rate.

\section{Thermodynamics of adsorption}

Thermodynamics of adsorption studies were performed at temperatures 300 and $330 \mathrm{~K}$. Plot of $\ln K_{\mathrm{d}}$ versus $1 / T$ gives rise to $\Delta H$ and $\Delta S$ as slope and intercept, respectively. Results obtained are summarized in Table $4 . \Delta G(-0.235$, -0.339 ) have shown negative values which confirm the feasibility of reactions at given temperatures (300 and $330 \mathrm{~K}$ ). Positive values of enthalpy $\Delta H$ (endothermic adsorption) and randomness $(\Delta S)$ indicate the feasibility of adsorption process (Li et al. 2008).

\section{Adsorption equilibrium}

\section{Langmuir isotherm model}

The value of $q_{\mathrm{m}}$ and $\mathrm{b}$ was calculated from the slope and intercept of plot between $c_{\mathrm{e}} / q_{\mathrm{e}}$ versus $c_{\mathrm{e}}$ (Fig. 7a). Obtained $q_{\mathrm{m}}$ in the present study was $97.43 \mathrm{mg} / \mathrm{g}$ (Table 5) which makes it a very reliable bioadsorbent. The correlation coefficient (0.9901) indicates the adsorption of cadmium ions on algal biomass followed Langmuir isotherm. The value of $R_{\mathrm{L}}$ for the adsorption was $0.014-0.031$ which makes it clear that this adsorption process is favourable.

\section{Freundlich isotherm model}

$K_{\mathrm{F}}$ is an adsorption constant that corresponds to adsorption capacity whereas $1 / n$ to the adsorption intensity. $n$ depends 
Fig. 5 a Effect of initial metal concentration on adsorption of Cd (II) on to Chlorella vulgaris biomass: $\mathrm{pH}=4.5$, dose $=1 \mathrm{~g} / \mathrm{L}$, contact time $=2 \mathrm{~h}$, room temperature. b Effect of initial metal concentration on adsorption of Cd (II) on to Chlorella vulgaris biomass: $\mathrm{pH}=4.5$, dose $=1 \mathrm{~g} / \mathrm{L}$, contact time $=2 \mathrm{~h}$, room temperature. $\mathbf{c}$ Effect of contact time on concentration on adsorption of Cd (II) on to Chlorella vulgaris biomass: $\mathrm{pH}=4.5$, initial concentration of $\mathrm{Cd}$ (II) $=100 \mathrm{mg} / \mathrm{L}$, dose $=1 \mathrm{~g} / \mathrm{L}$, room temperature. d Effect of biomass dosage on adsorption of Cd (II) on to Chlorella vulgaris biomass: $\mathrm{pH}=4.5, C_{\mathrm{i}}=100 \mathrm{mg} / \mathrm{L}$, contact time $=2 \mathrm{~h}$ and room temperature (a)

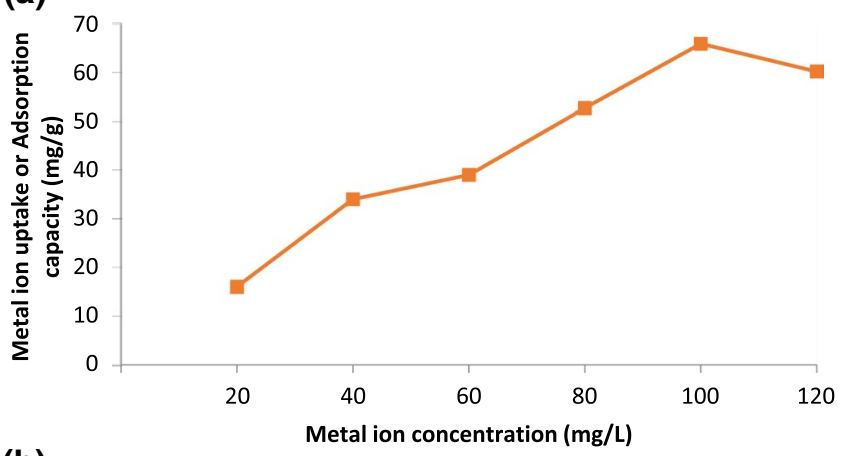

(b)

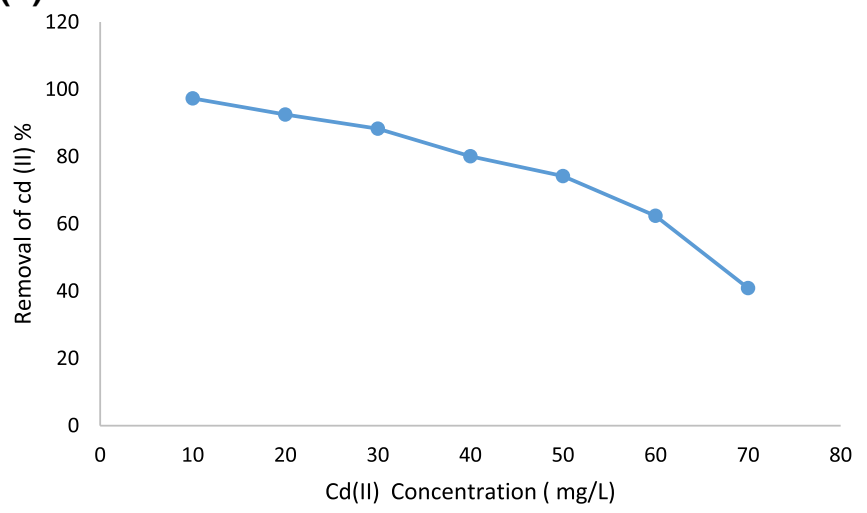

(c) 60

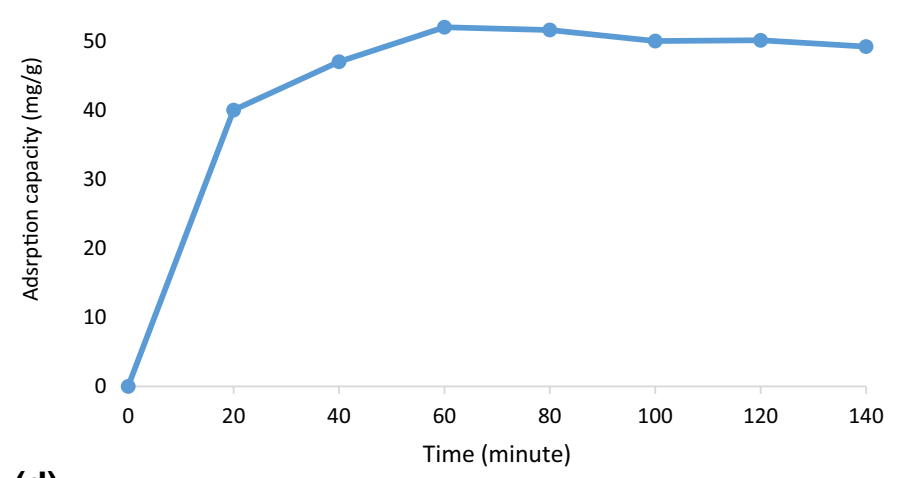

(d)

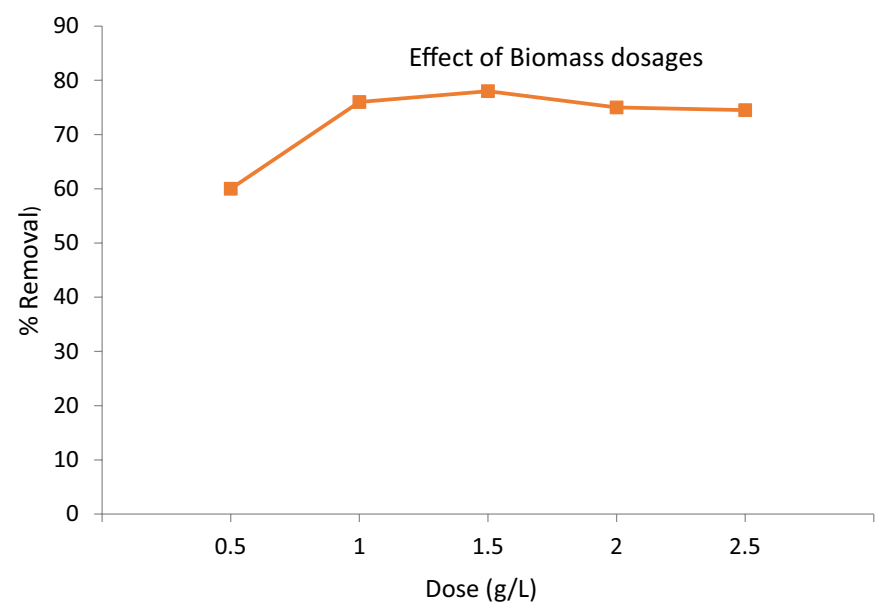


Table 3 Pseudo-first-order, pseudo-second-order and intraparticle diffusion rate for adsorption of $\mathrm{Cd}$ (II) on algal biomass

\begin{tabular}{ll}
\hline Constants & $\begin{array}{l}\text { Initial concentra- } \\
\text { tion }(100 \mathrm{mg} / \mathrm{L})\end{array}$ \\
\hline$q_{\mathrm{e} \text { exp. }(\mathrm{mg} / \mathrm{g})}$ & 62.3 \\
Pseudo-first-order & \\
$q_{\mathrm{e} \text { cal. } \mathrm{mg} / \mathrm{g})}$ & 24.9 \\
$K_{1}\left(\mathrm{~min}^{-1}\right)$ & 0.024 \\
$R^{2}$ & 0.956 \\
Pseudo-second-order & \\
$q_{\mathrm{e} \text { cal. }(\mathrm{mg} / \mathrm{g})}$ & 65.9 \\
$K_{2}\left(\mathrm{~g} \mathrm{mg}{ }^{-1} \mathrm{~min}^{-1}\right)$ & 0.0065 \\
$R^{2}$ & 0.9975 \\
Intraparticle diffusion & \\
$k_{\mathrm{id}}\left(\mathrm{mg} \mathrm{g}^{-1} \mathrm{~min}^{-1)}\right.$ & 2.67 \\
$R^{2}$ & 0.8681 \\
\hline
\end{tabular}

on the adsorbate and adsorbent. Plot of $q_{\mathrm{e}}$ versus $\ln c_{\mathrm{e}}$ gives rise to the value of $K_{\mathrm{f}}$ and $\mathrm{n}$ as shown in Fig. 7b. Value of $n$ (1.73) higher than unity favours the adsorption process (Table 5). When we compare the Langmuir and Freundlich adsorption isotherms of algal biomass for heavy metal ion Cd (II)) with the practical values given in Table 5 and Fig. 7a, b, we can easily figure out that both Langmuir isotherm and Freundlich isotherms display a higher regression coefficient $\left(R^{2}\right)$ as both models could fit but Langmuir isotherm model was the best fit to this adsorption process.

\section{Desorption studies and recyclability}

Cost effectiveness is one of the most important factors for industrial feasibility of bioadsorbent, so it is desirable to regenerate and reuse. Recyclability of algal bioadsorbent was evaluated by (0.1 Mof $\mathrm{HNO} 3, \mathrm{HCl}, \mathrm{H}_{2} \mathrm{SO}_{4}$ and EDTA). Results show that HNO3 $(0.1 \mathrm{~N})$ is a more effective eluting agent than the rest as shown in Fig. 8a. Since $\mathrm{HNO}_{3}$ can nitrify and damage the adsorbent in high concentration (Deng et al. 2008), it is not preferred as a desorbating agent rather EDTA is preferable because of its high affinity to form complex with $\mathrm{Cd}$ (II) without any damage to the algal adsorbent (Kordialik-Bogacka 2011).

Effect of EDTA concentration, temperature and time on desorption.

Desorption capacity over different EDTA concentrations was evaluated on the algal biosorbent. Results are shown in Fig. 8b. The desorption capacity increases with increase in the concentration of EDTA at the starting and then gets decreased. The reason might be, initially at low concentrations it desorbs $\mathrm{Cd}$ (II) by exchanging the ions but as we increase the concentration of EDTA the desorbed Cd (II) also gets accumulated and causes hindrance in desorbing $\mathrm{Cd}$
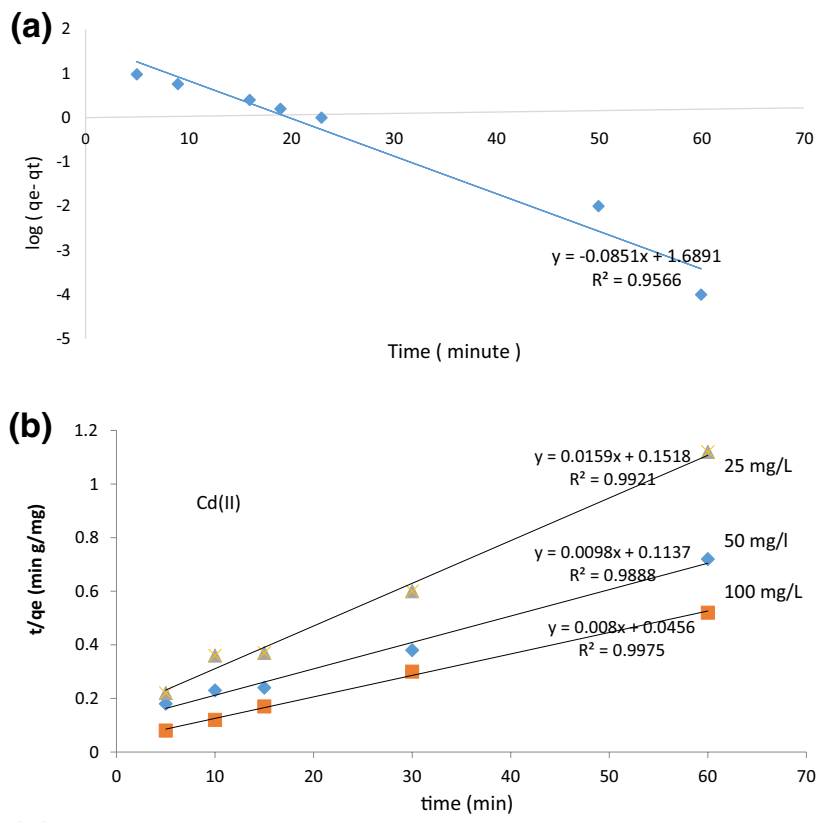

(c)

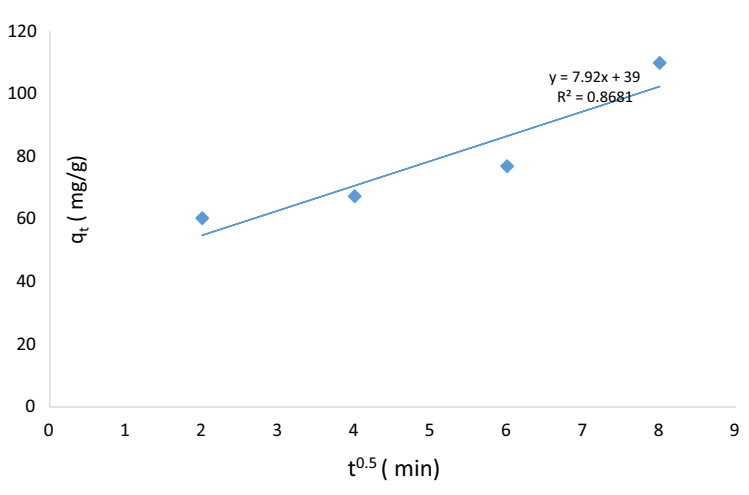

Fig. 6 a Pseudo-first-order plot for adsorption of Cd (II) on algal biomass: $\mathrm{pH}=4.5, C_{\mathrm{i}}=100 \mathrm{mg} / \mathrm{L}$. dose $=1 \mathrm{~g} / \mathrm{L}$, contact time $=60 \mathrm{~min}$ at room temperature. b Pseudo-second order plot for adsorption of $\mathrm{Cd}$ (II) on algal biomass: $\mathrm{pH}=4.5, \mathrm{C}_{\mathrm{i}}=25,50,100 \mathrm{mg} / \mathrm{L}$. dose $=1 \mathrm{~g} / \mathrm{L}$, contact time $=60 \mathrm{~min}$ at room temperature. c Intraparticle diffusion model for adsorption of $\mathrm{Cd}$ (II) on algal biomass: $\mathrm{pH}=4.5$, $\mathrm{C}_{\mathrm{i}}=100 \mathrm{mg} / \mathrm{L}$. dose $=1 \mathrm{~g} / \mathrm{L}$, contact time $=60 \mathrm{~min}$ at room temperature

(II) afterwards. The maximum desorption capacity of algal biomass was reached at $87.2 \mathrm{mg} / \mathrm{g}$ at an EDTA concentration of $0.1 \mathrm{~mol} / \mathrm{L}$.

The effects of different desorption temperatures on $\mathrm{Cd}$ (II)-loaded algal biomass desorption capacity are shown in Fig. 8c. The findings show that desorption capacity of algal biomass increases initially with increase in temperature till $55{ }^{\circ} \mathrm{C}$ but after this desorption capacity decreases sharply, which shows that the temperature range $\left(50-55^{\circ} \mathrm{C}\right)$ is the best for desorption(Jalali et al. 2002).

The effect of different desorption times on algal biomass was studied with EDTA of $0.1 \mathrm{~mol} / \mathrm{L}$ shown in Fig. 8d. Result shows that desorption capacity first increased, 
Table 4 Thermodynamic parameters

\begin{tabular}{lllllllc}
\hline $\begin{array}{l}\text { Tempera- } \\
\text { ture (K) }\end{array}$ & $1 / \mathrm{T}$ & $C_{\mathrm{e}}(\mathrm{g} / \mathrm{l})$ & $\mathrm{Kc}$ & $\mathrm{Log} \mathrm{kc}$ & $\Delta G(\mathrm{KJ} / \mathrm{mol})$ & $\Delta H(\mathrm{KJ} / \mathrm{mol})$ & $\Delta S(\mathrm{~J} / \mathrm{K} \mathrm{mol})$ \\
\hline 300 & 0.0033 & 0.039 & 0.334 & 0.476253 & -0.235 & 13.876 & 99.87 \\
330 & 0.0030 & 0.061 & 0.632 & 0.199282 & -0.339 & 21.901 & 107.7 \\
\hline
\end{tabular}

(a)

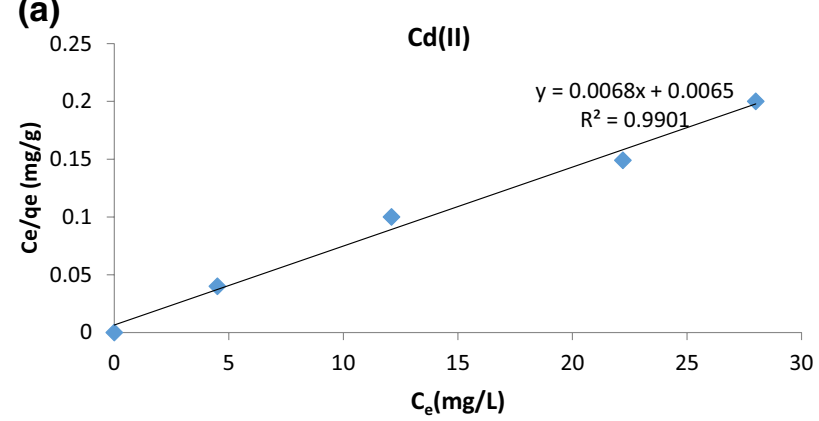

(b)

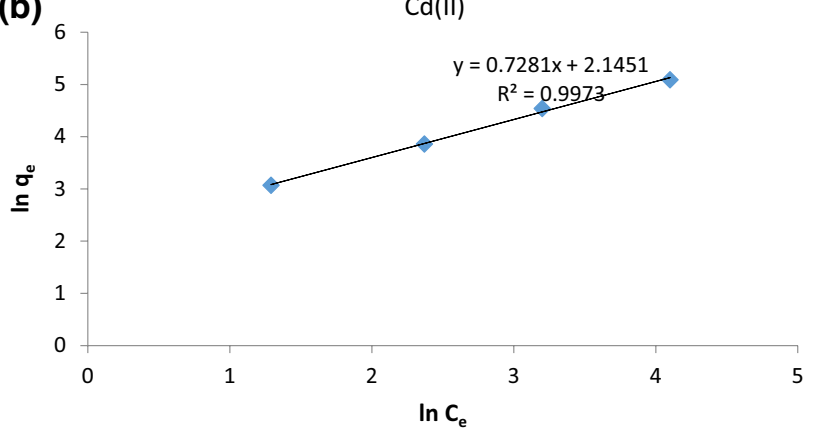

Fig. 7 a Langmuir isotherm plot for adsorption of $\mathrm{Cd}$ (II) on algal biomass of Chlorella vulgaris: $\mathrm{pH}=4.5, \mathrm{Ci}=25-100 \mathrm{mg} / \mathrm{L}$, dose $=1 \mathrm{~g} / \mathrm{L}$, time $=$ unit hour at room temperature. b Freundlich isotherm plot for adsorption of Cd (II) on algal biomass of Chlorella vulgaris: $\mathrm{pH}=4.5, \mathrm{Ci}=25-100 \mathrm{mg} / \mathrm{L}$, dose $=1 \mathrm{~g} / \mathrm{L}$, time $=$ unit hour at room temperature

Table 5 Langmuir and Freundlich adsorption isotherm constants and parameters for adsorption of $\mathrm{Cd}$ (II) on algal biomass

\begin{tabular}{lll}
\hline Isotherms & Constants & Algal biosorbent \\
\hline Langmuir Cd (II) & $q_{\mathrm{m}}(\mathrm{mg} / \mathrm{g})$ & 97.43 \\
& $\mathrm{~b}(\mathrm{~L} / \mathrm{mg})$ & 0.290 \\
& $\mathrm{R}^{2}$ & 0.990 \\
& $\mathrm{R}_{\mathrm{L}}$ & $0.014-0.031$ \\
Freundlich Cd (II) & $K_{\mathrm{f}}(\mathrm{mg} / \mathrm{g})$ & 36.17 \\
& $\mathrm{n}$ & 1.73 \\
& $\mathrm{R}^{2}$ & 0.997 \\
\hline
\end{tabular}

reached maximum at $55 \mathrm{~min}$ and again decreased with time. The cause for this result might be initially EDTA had high capacity (unoccupied sites) to attract metal ions but after getting saturated with coordination bond with metal ions the sites occupied and desorption capacity decreased

To investigate its reproducibility of algal biomass, five cycles of adsorption and desorption were repeated at fixed optimum conditions (temp $55^{\circ} \mathrm{C}$, biomass dose $0.1 \mathrm{~g}$, time $55 \mathrm{~min}$, EDTA concentration $0.1 \mathrm{~mol} / \mathrm{L}$ ). Investigated results showed that removal efficiency was decreased from 84.2 to 79.3 after five cycles which reveal its applicability in industrial purpose.

\section{Conclusions}

The results obtained in this study demonstrated that isolated Chlorella vulgaris that is easily available at very low cost could be very effective in the removal of heavy metal Cd (II) not only among algal biomass (Jalali et al. 2002; Lodeiro et al. 2006)but also among other low-cost biomasses comparatively (López-Mesas et al. 2011; Lalhruaitluanga et al. 2010). The sorption capacity of algal biomass at initial concentration $100 \mathrm{ppm}, \mathrm{pH} 4.5-5$ at room temperature was 62.3 which is quite fast and equilibrium reached within one hour. FTIR and SEM studies validated the interaction between various functional groups present on the surface of adsorbent and heavy metals. Biosorption data fit well to Langmuir isotherm model and partially to Freundlich. Experimental results suggest that pseudo-second-order reaction kinetics was followed by biosorption, and it seems other than intraparticle diffusion other kinetic models are also responsible for controlling the rate of reactions. 0.1 N EDTA was a good eluting agent at $55{ }^{\circ} \mathrm{C}$ temperature taking about one hour time. Regeneration also seems effective, but further assessment of economic study is needed for industrial upscaling. In this context, the development of commercial biosorbents by immobilization techniques would be very effective. 
Fig. 8 a Cd (II) recovery by different desorbents. b Effect of EDTA concentration on desorption capacity of algal biomass (sample dose $0.1 \mathrm{~g}$, temperature $55^{\circ} \mathrm{C}$; time $45 \mathrm{~min}$ ). c Effect of temperature on desorption capacity of algal biomass. (sample dose $0.1 \mathrm{~g}$, EDTA concentration $0.1 \mathrm{~mol} / \mathrm{L}$; time $45 \mathrm{~min}$.) d Effect of time on desorption capacity of algal biomass. (sample dose $0.1 \mathrm{~g}$, EDTA concentration, $0.1 \mathrm{~mol} / \mathrm{L}$.) (a)

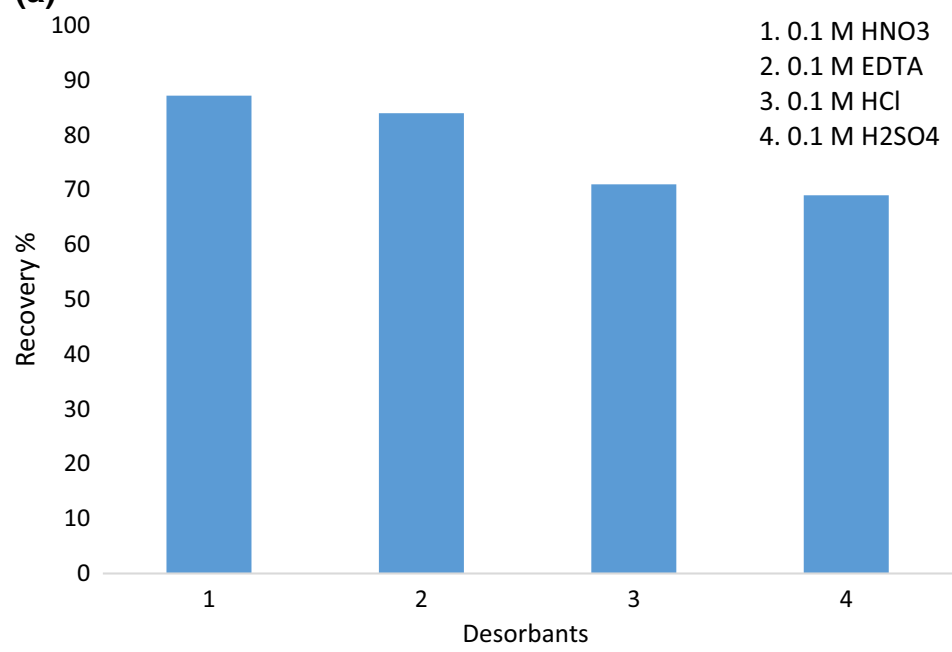

(b)

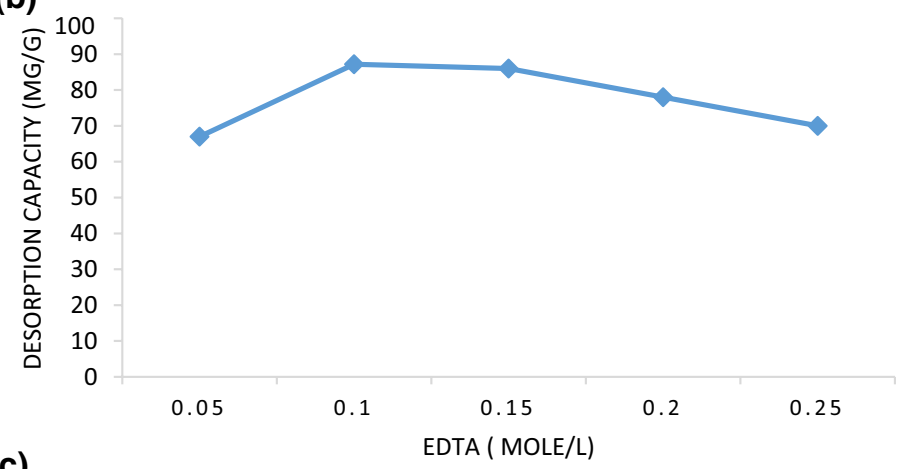

(c)

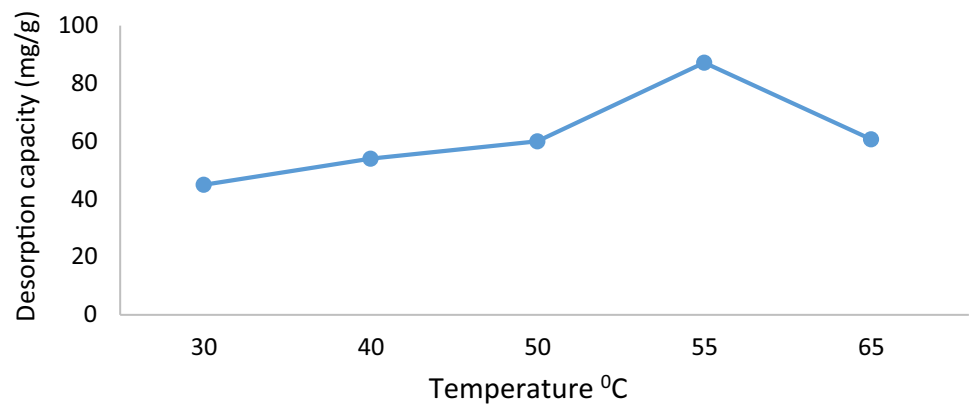

(d) 100

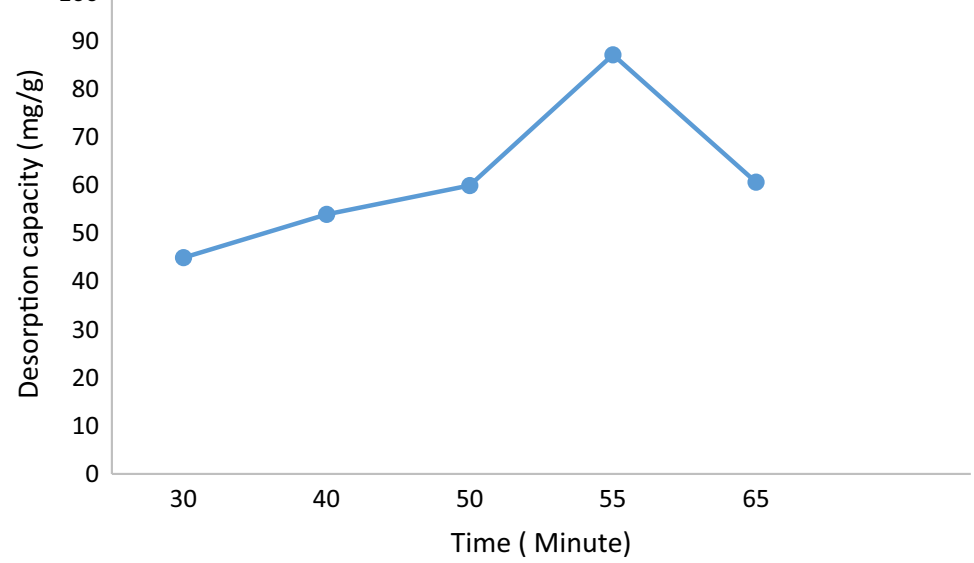


Open Access This article is distributed under the terms of the Creative Commons Attribution 4.0 International License (http://creativeco mmons.org/licenses/by/4.0/), which permits unrestricted use, distribution, and reproduction in any medium, provided you give appropriate credit to the original author(s) and the source, provide a link to the Creative Commons license, and indicate if changes were made.

\section{References}

Aksu Z (2002) Determination of the equilibrium, kinetic and thermodynamic parameters of the batch biosorption of nickel (II) ions onto Chlorella vulgaris. Process Biochem 38(1):89-99

Azizian S (2004) Kinetic models of sorption: a theoretical analysis. J Colloid Interface Sci 276(1):47-52

Becker EW (1994) Microalgae: biotechnology and microbiology, vol 10. Cambridge University Press, Cambridge

Blöcher C et al (2003) Hybrid flotation-membrane filtration process for the removal of heavy metal ions from wastewater. Water Res 37(16):4018-4026

Chen J-Z et al (2005) Biosorption of lead, cadmium and mercury by immobilized Microcystis aeruginosa in a column. Process Biochem 40(12):3675-3679

Deng L et al (2008) Biosorption and desorption of $\mathrm{Cd}^{2+}$ from wastewater by dehydrated shreds of Cladophora fascicularis. Chin J Oceanol Limnol 26(1):45-49

Eccles H (1999) Treatment of metal-contaminated wastes: why select a biological process? Trends Biotechnol 17(12):462-465

Freundlich H (1907) Über die adsorption in lösungen. Z Phys Chem 57(1):385-470

Hashim MA, Chu KH (2004) Biosorption of cadmium by brown, green, and red seaweeds. Chem Eng J 97(2-3):249-255

Ho Y-S, McKay G (1999) Pseudo-second order model for sorption processes. Process Biochem 34(5):451-465

Ho Y-S, Chiu W-T, Wang C-C (2005) Regression analysis for the sorption isotherms of basic dyes on sugarcane dust. Biores Technol 96(11):1285-1291

Holan ZR, Volesky B (1994) Biosorption of lead and nickel by biomass of marine algae. Biotechnol Bioeng 43(11):1001-1009

Ibrahim MB, Sani S (2014) Comparative isotherms studies on adsorptive removal of Congo red from wastewater by watermelon rinds and neem-tree leaves. Open J Phys Chem 4(4):139-146

Ibrahim SC, Hanafiah M, Yahya MZA (2006) Removal of cadmium from aqueous solutions by adsorption onto sugarcane bagasse. Am Eurasian J Agric Environ Sci 1(3):179-184

Jalali R et al (2002) Removal and recovery of lead using nonliving biomass of marine algae. J Hazard Mater 92(3):253-262

Järup L et al (1998) Health effects of cadmium exposure-a review of the literature and a risk estimate. Scand J Work Environ Health 24:1-51

Katırcıoğlu H et al (2008) Removal of cadmium (II) ion from aqueous system by dry biomass, immobilized live and heat-inactivated Oscillatoria sp. H1 isolated from freshwater (Mogan Lake). Biores Technol 99(10):4185-4191

Kordialik-Bogacka E (2011) Cadmium and lead recovery from yeast biomass. Cent Eur J Chem 9(2):320-325

Lagergren S (1898) Zur theorie der sogenannten adsorption geloster stoffe. Kungliga svenska vetenskapsakademiens. Handlingar 24:1-39

Lalhruaitluanga $\mathrm{H}$ et al (2010a) Lead (II) adsorption from aqueous solutions by raw and activated charcoals of Melocanna baccifera Roxburgh (bamboo) - a comparative study. J Hazard Mater 175(1-3):311-318

Lalhruaitluanga $\mathrm{H}$ et al (2010b) Lead (II) adsorption from aqueous solutions by raw and activated charcoals of Melocanna baccifera Roxburgh (bamboo) - a comparative study. J Hazard Mater 175(1-3):311-318
Langmuir I (1916) The constitution and fundamental properties of solids and liquids. Part I. Solids. J Am Chem Soc 38(11):2221-2295

Leyva-Ramos R et al (1997) Adsorption of cadmium (II) from aqueous solution onto activated carbon. Water Sci Technol 35(7):205-211

Li W et al (2008) Tobacco stems as a low cost adsorbent for the removal of $\mathrm{Pb}$ (II) from wastewater: equilibrium and kinetic studies. Ind Crops Prod 28(3):294-302

Lodeiro P et al (2006) The marine macroalga Cystoseira baccata as biosorbent for cadmium (II) and lead (II) removal: kinetic and equilibrium studies. Environ Pollut 142(2):264-273

López-Mesas M et al (2011) Bioseparation of $\mathrm{Pb}$ (II) and Cd (II) from aqueous solution using cork waste biomass. Modeling and optimization of the parameters of the biosorption step. Chem Eng J 174(1):9-17

Mane VS, Mall ID, Srivastava VC (2007) Kinetic and equilibrium isotherm studies for the adsorptive removal of Brilliant Green dye from aqueous solution by rice husk ash. J Environ Manag 84(4):390-400

McGinn PJ et al (2012) Assessment of the bioenergy and bioremediation potentials of the microalga Scenedesmus sp. AMDD cultivated in municipal wastewater effluent in batch and continuous mode. Algal Res 1(2):155-165

Mohapatra M, Anand S (2007) Studies on sorption of Cd (II) on Tata chromite mine overburden. J Hazard Mater 148(3):553-559

Nasir MH et al (2007) Efficacy of modified distillation sludge of rose (Rosa centifolia) petals for lead (II) and zinc (II) removal from aqueous solutions. J Hazard Mater 147(3):1006-1014

Nordberg GF (2009) Historical perspectives on cadmium toxicology. Toxicol Appl Pharmacol 238(3):192-200

Oliveira WE et al (2008) Untreated coffee husks as biosorbents for the removal of heavy metals from aqueous solutions. J Hazard Mater 152(3):1073-1081

Patterson JW (1985) Industrial wastewater treatment technology, 2nd edn. Butterworth Publishers, Stoneham

Pauling L (1960) The nature of the chemical bond, vol 260. Cornell University Press, Ithaca

Piotrowska-Niczyporuk A et al (2012) Phytohormones as regulators of heavy metal biosorption and toxicity in green alga Chlorella vulgaris (Chlorophyceae). Plant Physiol Biochem 52:52-65

Ramelow GJ, Fralick D, Zhao Y-f (1992) Factors affecting the uptake of aqueous metal ions by dried seaweed biomass. Microbios 72(291):81-93

Rao M Gopala, Gupta AK (1982) Ion exchange processes accompanied by ionic reactions. Chem Eng J 24(2):181-190

Sethi PK, Khandelwal D, Sethi N (2006) Cadmium exposure: health hazards of silver cottage industry in developing countries. J Med Toxicol 2(1):14-15

Sharma A, Bhattacharyya KG (2005) Azadirachta indica (Neem) leaf powder as a biosorbent for removal of $\mathrm{Cd}$ (II) from aqueous medium. J Hazard Mater 125(1-3):102-112

Shen W, Li Z, Liu Y (2008) Surface chemical functional groups modification of porous carbon. Recent Patents Chem Eng 1(1):27-40

Tunali S, Cabuk A, Akar T (2006) Removal of lead and copper ions from aqueous solutions by bacterial strain isolated from soil. Chem Eng J 115(3):203-211

Weber WJ, Carrell Morris J (1963) Kinetics of adsorption on carbon from solution. J Sanit Engi Div 89(2):31-60

Yadav SK, Singh DK, Sinha S (2013) Adsorption study of lead (II) onto xanthated date palm trunk: kinetics, isotherm and mechanism. Desalin Water Treat 51(34-36):6798-6807

Yadav SK, Singh DK, Sinha S (2014) Chemical carbonization of papaya seed originated charcoals for sorption of $\mathrm{Pb}(\mathrm{II})$ from aqueous solution. J Environ Chem Eng 2(1):9-19

Publisher's Note Springer Nature remains neutral with regard to jurisdictional claims in published maps and institutional affiliations.

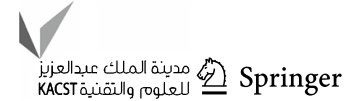

